Atmos. Chem. Phys., 19, 10525-10535, 2019

https://doi.org/10.5194/acp-19-10525-2019

(C) Author(s) 2019. This work is distributed under

the Creative Commons Attribution 4.0 License.

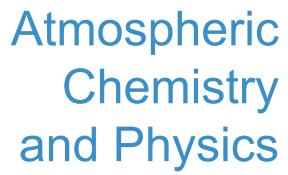

(c) (P)

\title{
Evaluating the relative importance of northern African mineral dust sources using remote sensing
}

\author{
Natalie L. Bakker ${ }^{1}$, Nick A. Drake ${ }^{1}$, and Charlie S. Bristow ${ }^{2}$ \\ ${ }^{1}$ Department of Geography, King's College London, University of London, London, UK \\ ${ }^{2}$ Department of Earth and Planetary Sciences, Birkbeck College, University of London, London, UK
}

Correspondence: Natalie L. Bakker (natalie.bakker@kcl.ac.uk)

Received: 15 March 2019 - Discussion started: 16 April 2019

Revised: 21 June 2019 - Accepted: 11 July 2019 - Published: 21 August 2019

\begin{abstract}
Northern African mineral dust provides the Amazon Basin with essential nutrients during the boreal winter months, when the trajectory of the Saharan dust plume is towards South America. This process, however, is still poorly understood. There is little knowledge of where the dust is coming from, and, thus, little information regarding the concentration of nutrients in the dust. This information is vital to assess the impact it will have on the Amazon. In order to further our understanding of the problem, this study analyses northern African dust sources of the boreal winter dust seasons between the years 2015 and 2017. It utilises high spatio-temporal resolution remote sensing data from SEVIRI, MODIS, VIIRS, and Sentinel-2 to identify dust sources, classify them according to a geomorphic dust source scheme, and quantify the relative importance of source regions by calculating the total dust mass they produce. Results indicate that palaeolakes emit the most dust, with the Bodélé Depression as the single largest dust source region. However, alluvial deposits also produce a substantial amount of dust. During the boreal winter dust seasons of 2015-2017, $\sim 36 \%$ of the total dust mass emitted from northern Africa was associated with alluvial deposits, yet this geomorphic category has been relatively understudied to date. Furthermore, sand deposits were found to produce relatively little dust, in contrast to the results of other recent studies.
\end{abstract}

\section{Introduction}

Mineral dust is an important component of the Earth system, affecting radiative forcing, cloud properties, and playing a key role in terrestrial, oceanic, atmospheric, and biogeochemical exchanges (Harrison et al., 2001; Jickells et al., 2005; Mahowald et al., 2010). The Sahara and the Sahel are the world's largest dust source regions, emitting several hundred teragrams of mineral dust yearly (Ridley et al., 2012). Most of this dust is carried over large distances and transported west and southwest across the Atlantic Ocean (Chiapello et al., 1997). During the boreal summer dust is blown by the trade winds from northern Africa towards the Caribbean, whereas during winter it takes a more southerly route towards the Amazon Basin. It has been suggested that this dust has a significant fertilising effect on the nutrientdeficient Amazonian rainforest soils (Swap et al., 1992; Yu et al., 2015). In order to better understand past, current, and future impacts of northern African mineral dust on the Amazon Basin, the biogeochemical properties of the dust need to be determined. Recently it has been shown that these properties differ significantly based on the geology and geomorphology of the terrestrial source (Gross et al., 2015, 2016); therefore, it is critical to precisely identify dust sources and their geomorphic nature.

Previous dust source identification studies have used geochemistry and mineralogy of dust samples, satellite remote sensing techniques, or back trajectory analysis (Schepanski et al., 2012; Scheuvens et al., 2013; Muhs et al., 2014). In the latter case, the performance of trajectory models is highly dependent on the initial conditions, and it is restricted by the quality of the input data (Gebhart et al., 2005). Tracing sources using the geochemistry and mineralogy of dust sam- 
ples proves difficult for Saharan dust, as samples are sporadic in time and space, and transport affects measurements in poorly understood ways (Formenti et al., 2011). Satellite remote sensing in comparison, provides high spatio-temporal data across the region and has been found to be an effective method of identifying dust source areas (Prospero et al., 2002; Washington et al., 2003; Schepanski et al., 2012). Notwithstanding, many remote sensing techniques identify erroneous sources as they average both emission and transport (Prospero et al., 2002; Washington et al., 2003); thus, methods need to be adopted that only identify the site of dust emission (Schepanski et al., 2012; Ashpole and Washington, 2013).

While the major dust source areas within the Sahara and the Sahel have been identified using remote sensing (Prospero et al., 2002; Schepanski et al., 2009; Ginoux et al., 2012; Ashpole and Washington, 2013), only a few studies classify the geomorphology of these sources (Crouvi et al., 2012; Ashpole and Washington, 2013), and knowledge of the relative importance of the major dust regions is lacking. Studies analysing the fertilisation effect of dust on the Amazon focus primarily on the impact of palaeolake Bodélé (Bristow et al., 2010; Yu et al., 2015) as this has been shown to be the most important source region (Koren et al., 2006; Ben-Ami et al., 2010). The latest estimates of phosphorous input into the Amazon are based solely on the phosphorous concentration in Bodélé dust (Yu et al., 2015), but this is unlikely to reflect the diversity of the surfaces producing dust.

The aim of this study is to identify wintertime dust sources, as only this dust is transported to the Amazon. The sources are classified according to the geomorphic dust source scheme developed by Bullard et al. (2011), after which the importance of the various dust sources is quantified, and the amount of dust each region produces is calculated. This is achieved via a combination of remote sensing products with different temporal and spatial resolutions, to optimise the identification of dust storms, dusts source regions, and the geomorphology of individual dusts sources. The Spinning Enhanced Visible and Infrared Imager (SEVIRI) dust red, green, blue (RGB) colour composite has a high temporal resolution and is used here to detect dust storms, whereas the Visible Infrared Imaging Radiometer Suite (VIIRS) dust RGB with higher spatial resolution is utilised to accurately determine the dust source locations. The Moderate Resolution Imaging Spectroradiometer (MODIS) aerosol optical depth product is employed to quantify how much dust the sources produce, and the high spatial resolution $(10 \mathrm{~m})$ Sentinel-2 true colour composite is used to identify the geomorphology of each source. The study examines the dust storms of the 2015-2017 winter dust seasons. Both the number of individual dust sources of each geomorphological class, as well as the total dust mass emitted per class and dust source region are estimated.

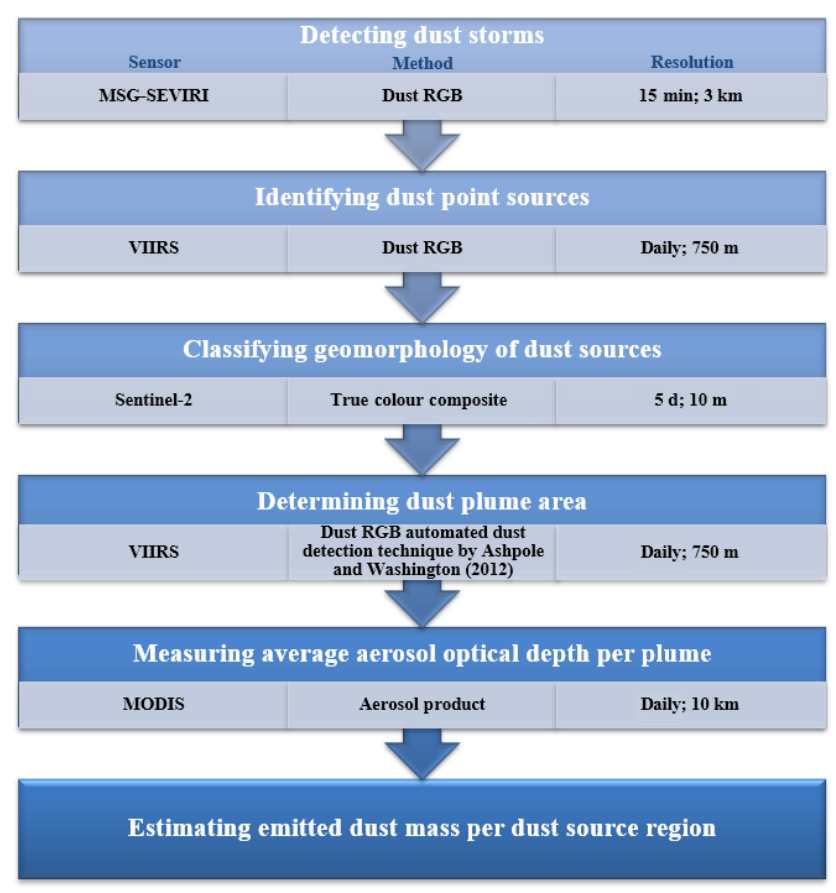

Figure 1. Overview of the methodology of the study. The remote sensing sensor used in each step is presented in the left column, the image processing method employed is shown in the middle column, and the resolution (temporal; spatial) is shown in the right column.

\section{Methodology}

The study analyses northern African dust sources during the boreal wintertime, defined as the area between the latitudes 5 and $40^{\circ} \mathrm{N}$ and the longitudes $20^{\circ} \mathrm{W}$ and $40^{\circ} \mathrm{E}$. The dust seasons analysed run between 1 December 2015 and 29 February 2016 and 1 December 2016 and 28 February 2017, following the wintertime dust months of Schepanski et al. (2009). Figure 1 provides a complete overview of the data and methodology.

\subsection{Detecting dust storms}

MSG-SEVIRI was utilised to detect dust storms every $15 \mathrm{~min}$ at a spatial resolution of $3 \mathrm{~km}$ at nadir. The dust RGB method of Lensky and Rosenfeld (2008) was employed, whereby infrared channels are utilised to produce an image in which dust is portrayed in a pink colour. To achieve this, the red band is allocated the brightness temperature difference (BTD) between channels at 12 and $10.8 \mu \mathrm{m}$, green the BTD between channels at 10.8 and $8.7 \mu \mathrm{m}$, and blue the brightness temperature (BT) of the $10.8 \mu \mathrm{m}$ channel. Processed SEVIRI dust RGB images were acquired from the database of the FENNEC project (FENNEC, 2019). By visually interpreting images, all dust events of the 2015-2017 boreal winter dust seasons were identified. Although the high temporal resolution of SEVIRI makes it suitable for observing the evolution of dust storms (Schepanski et al., 2009, 2012; Ashpole and 


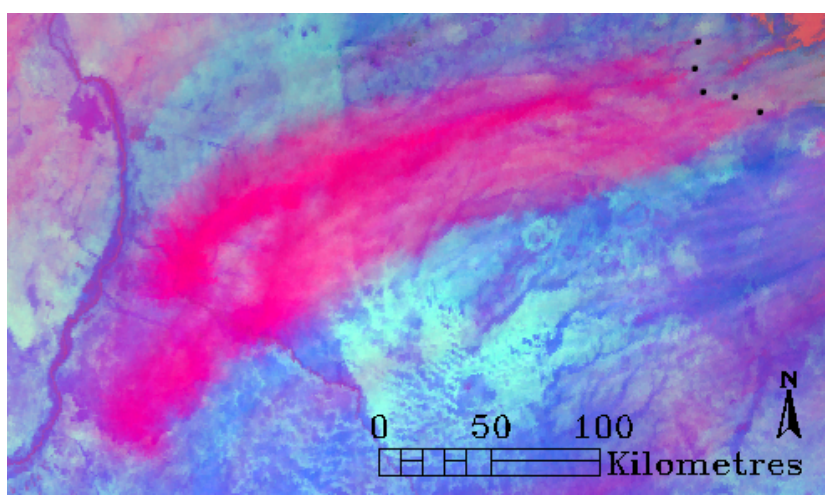

Figure 2. VIIRS Dust RGB (Lensky and Rosenfeld, 2008) showing dust being emitted northeast of the Sudanese Nile (latitude $18^{\circ}$, longitude $35^{\circ}$ ) on 19 December 2016. Dust point source locations are identified by tracking dust plumes back to their first point of occurrence.

Washington, 2012), its low spatial resolution means it is less suited for determining the precise location and nature of the sources.

\subsection{Identifying dust point sources}

VIIRS was used to identify dust point sources as it is currently the sensor with the highest spatial resolution that has a daily temporal resolution; it has 5 imaging-resolution bands (I-bands) at a $375 \mathrm{~m}$ resolution, and 16 moderate-resolution bands (M-bands) at a $750 \mathrm{~m}$ resolution. The same dust RGB method was employed using the infrared M-bands, centred at $8.55,10.76$, and $12.01 \mu \mathrm{m}$. Dust point sources were identified manually using visual interpretation. The individual dust plumes were tracked upwind back to their first point of occurrence (see Fig. 2), except for those forming under clouds (dust storms with sources under clouds were visible on approximately $2 \mathrm{~d}$ per month; thus, this was not a significant problem). As this process is labour intensive, this step was only performed on the 10 largest dust storms (in areal coverage) of each dust season; i.e. a total of 20 dust storms were analysed in this step.

\subsection{Classifying geomorphology of dust sources}

The geomorphology of the dust point sources of the 20 largest dust storms was analysed using Sentinel-2 imagery. This sensor collects visible, near-infrared, and short-wave infrared imagery at a spatial resolution of $10-60 \mathrm{~m}$, and a temporal resolution of $5 \mathrm{~d}$. Using the $10 \mathrm{~m}$ resolution true colour composites, it is possible to distinguish many geomorphic features within the imagery. Cloud free, Level-1C Sentinel-2 data were obtained for each of the dust point source locations identified from the VIIRS data. Each point source was interpreted and allocated to one of the geomorphic classes described by Bullard et al. (2011). These classes are based on differences in surface characteristics governing their susceptibility of aeolian erosion, provided they meet the criteria to be readily identifiable from remote sensing data. The classes from the scheme identified in this study are "palaeolakes", "alluvial deposits", "stony surfaces", and "sand deposits". Furthermore, the class "anthropogenic" was added to the classification scheme, defined as dust sources linked to urban areas, villages, roads, and agricultural lands. Examples of the various geomorphic classes can be found in Appendix A. Drake et al. (2008) demonstrated that the geomorphic classification scheme could characterise dust sources in the western Sahara region successfully. To account for the spatial resolution differences between VIIRS and Sentinel-2, point sources were classified as the most prominent feature and/or the most common geomorphic class within $750 \mathrm{~m}$ of the point location determined with VIIRS.

The identified point sources tended to spatially cluster into 12 major dust source regions according to their geomorphological type (Fig. 3). In most regions, a single geomorphological source class dominated, and a predominant geomorphology per region could be determined. In two cases, namely in the southern Air and El Eglab dust source regions, there was no single predominant geomorphic class; thus, they were classified as mixed palaeolake and alluvial deposit $(50 / 50 \%)$. Once the major dust source regions were established, all dust plumes of the 2015-2017 wintertime dust seasons were assigned to the nearest major source region based on its upwind edge and then assigned the predominant geomorphic class of the region they originated from. A further four prominent dust source regions were added (see regions with dashed outlines in Fig. 3), which emitted dust plumes during the two winter dust seasons, although they did not emit during the 20 largest dust storms. The predominant geomorphology of these regions was determined separately via visual interpretation of Sentinel-2 data using the same methods that were employed for the 20 largest dust storms.

The accuracy of using only the 20 largest dust storm days of the two seasons to determine the major dust regions and their predominant geomorphology was evaluated by randomly selecting 3 additional days (29 December 2015, 21 January 2017, and 8 February 2017), identifying all point sources of these days, analysing the geomorphic class of each detected point source, and subsequently determining what percentage of these dust point sources coincided with those defined by the map of predominant dust geomorphologies. The geomorphological classes of a further 163 dust point sources were identified from the 3 randomly chosen days. Of the 163 dust point sources, $161(98.77 \%)$ corresponded to the predominant geomorphology assigned to the region.

\subsection{Determining dust plume area}

After the main dust source regions were determined, the next step was to estimate how much dust was emitted per region. To do so, firstly, the dust plume area was calculated for 


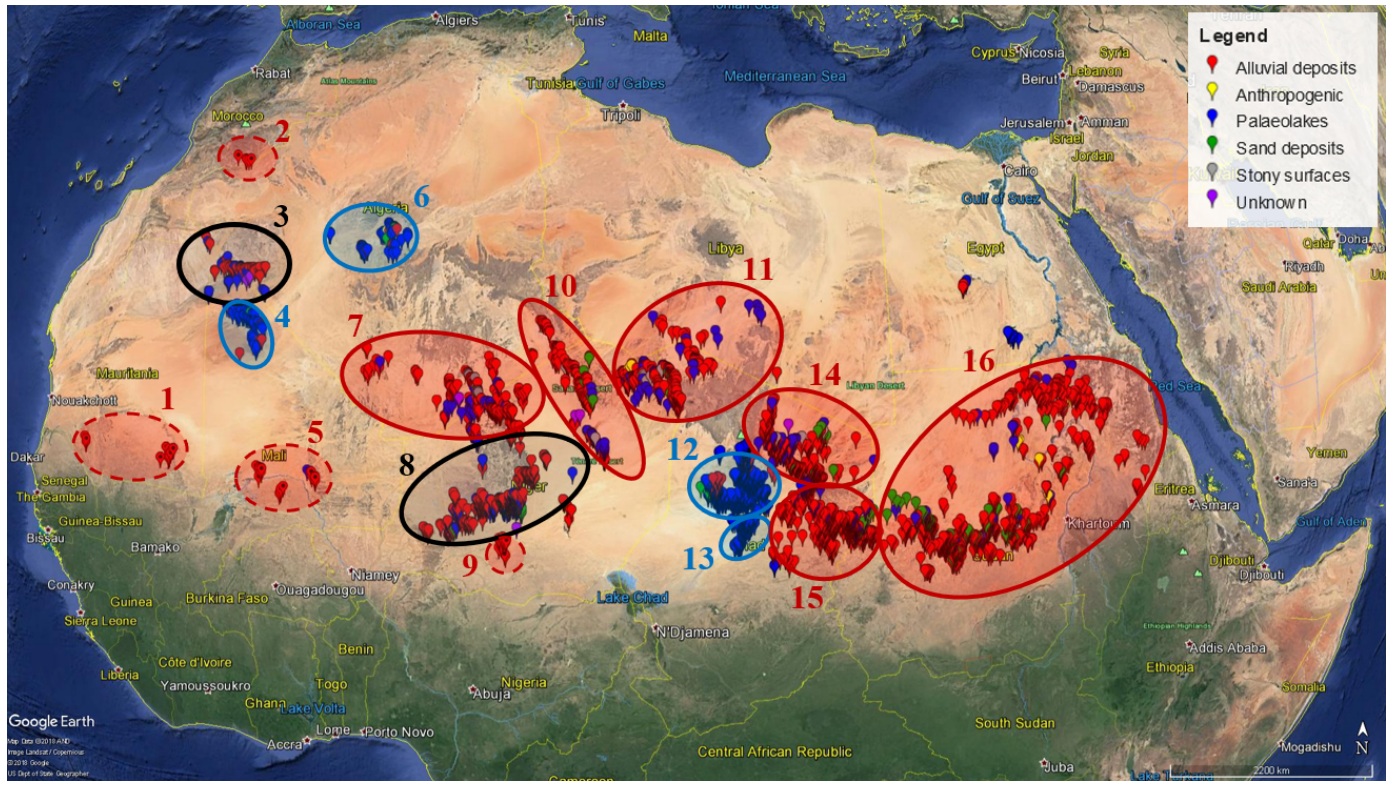

Figure 3. Geomorphology of the northern African mineral dust sources of the 2015-2017 boreal winter dust seasons. Coloured pins represent individual dust point sources of the 20 largest dust storms of the 2015-2017 winter dust seasons, with the colour signifying the geomorphic category of the dust point source. The major dust source regions are outlined, with red regions containing predominantly alluvial deposit dust sources, blue regions containing predominantly palaeolake dust sources, and black regions containing a mixture of alluvial deposit and palaeolake dust sources. The regions with dashed outlines were regions that emitted dust during the dust seasons, but did not emit during the 20 largest dust storms of the 2015-2017 winter dust seasons. Source areas are numbered as follows: 1 - Mauritania, 2 - Draa River, 3 - El Eglab, 4 - northwest Mali, 5 - mid-Mali, 6 - Algeria, 7 - northern Air, 8 - southern Air, 9 - southern Niger, 10 - Djado Plateau, 11 - Tibesti, 12 - Bodélé, 13 - Bahr el Gazel, 14 - upper Bodélé, 15 - Ennedi, and 16 - Sudan. Background @Google Earth, imagery Landsat/Copernicus (2018).

all dust plumes of the 2015-2017 wintertime dust seasons using the automated dust detection technique developed by Ashpole and Washington (2012). In this method, the following thresholds are applied to the brightness temperatures (in Kelvin) of the $10.76,12.01$, and $8.55 \mu \mathrm{m}$ channels of VIIRS imagery:

$$
\begin{aligned}
& \text { BT } 10.76 \geq 285 \\
& \text { BTD }(12.01-10.76) \geq 0 \\
& \text { BTD }(10.76-8.55) \leq 10
\end{aligned}
$$

Background surface features that were incorrectly detected as dust were removed manually, after which dust plumes could be outlined and their size calculated. The methodology is objective, easily reproducible, fast, and was found to be consistent for moderate-to-heavy dust storms occurring during daytime hours (Ashpole and Washington, 2012). The method was applied to VIIRS, rather than SEVIRI or MODIS, due to its higher spatial resolution and its seamless continuation between swaths.

\subsection{Measuring average aerosol optical depth per plume}

In order to determine the concentration of dust within the dust plumes, the average (arithmetic mean) aerosol optical depth (AOD) per dust plume was calculated for all dust storms of the 2015-2017 wintertime seasons. As the VIIRS AOD product was found to contain large data gaps, particularly over bright desert surfaces, the MODIS aerosol product (MOD04_L2, MYD04_L2) was employed. MODIS monitors AOD on a daily basis at a $10 \mathrm{~km}$ spatial resolution, and combines the MODIS Dark Target (Kaufman et al., 1997; Levy et al., 2013) and MODIS Deep Blue (Hsu et al., 2004) algorithms. MODIS Dark Target uses the spectral radiances between 0.47 and $2.1 \mu \mathrm{m}$ to measure AOD over oceans and dark land surfaces. MODIS Deep Blue is designed to analyse aerosols over bright-reflecting surfaces, such as deserts, utilising measurements from the blue wavelengths (412 and $470 \mathrm{~nm}$ ). The combined algorithms allow MODIS to record data across northern Africa consistently (Sayer et al., 2013).

The methodology presented here does have the following limitations: (1) The once daily temporal resolution of MODIS, as dust storms in northern Africa can form during any time of the day (Schepanski et al., 2012), which causes a few dust storms to be missed. Nevertheless, the vast majority of dust storms in northern Africa initiate in the morning between the hours of 06:00 and 12:00 LT (local time) (Schepanski et al., 2009), and the dust storms in this study were observed to span several hours, such that the MODIS mean overpass time of 13:30 LT covered nearly all dust emis- 
sions; albeit dust plumes emitting after 13:30 LT were missed (which occurred on 1-2 d per season). (2) The MODIS and VIIRS overpass times are close but not identical, varying up to $20 \mathrm{~min}$. (3) Dust storm days between 19 and 27 February 2016 had to be omitted from this study due to a MODIS technical outage, during which the satellite did not log any data; hence, there were no MODIS AOD data available for this period.

\subsection{Estimating emitted dust mass per dust source region}

The dust mass for all dust plumes of the 2015-2017 wintertime seasons was estimated by combining the dust plume area data with the average MODIS AOD. The dust column concentration equation by Kaufman et al. (2005) was applied to all dust storms, whereby dust mass is determined using the relationship between plume size and average dust AOD at $550 \mu \mathrm{m}$ :

$M_{\mathrm{du}}=2.7 A \tau_{\mathrm{du}}$,

where $M_{\mathrm{du}}$ is dust mass, $A$ is the dust plume area, and $\tau_{\mathrm{du}}$ is the average AOD at $550 \mu \mathrm{m}$. The coefficient of 2.7 is derived through the extinction efficiency of 0.37 measured by Haywood et al. (2003). However, a more recent review of mass extinction efficiency measurements by Ansmann et al. (2012) shows higher reported values ranging between 0.37 and 0.57 . An updated Kaufman equation was derived using the extinction efficiency of 0.57 , resulting in a coefficient of 1.75 :

$M_{\mathrm{du}}=1.75 A \tau_{\mathrm{du}}$

Using Eqs. (2) and (3), the dust mass range was estimated (i.e. Eq. (3) for the lower limit, Eq. (2) for the upper limit). Ben-Ami et al. (2010) demonstrated that the Kaufman equation could successfully be used to calculate dust mass over northern Africa, although it should be noted that the equation has a relatively high uncertainty of $\pm 30 \%$ for AOD values between 0.2 and 0.4 and has potentially even greater errors for AOD values above 0.4 .

Once the dust mass per dust plume was estimated, dust plumes were grouped per dust source region and per geomorphology, and as such the total dust mass per region and dust mass per geomorphic class could be estimated.

\section{Results}

From the 20 largest dust storms, a total of 3512 individual dust point sources were identified (see Fig. 3). The dust point sources per geomorphological class are shown in Table 1; the vast majority were associated with alluvial deposits $(51.11 \%)$ or palaeolakes $(42.85 \%)$. Sand deposits, including dune fields and sand sheets, accounted for only $3.93 \%$. A few sources were linked to anthropogenic influences, such as villages, dirt roads, or agricultural fields. Moreover, 22 point

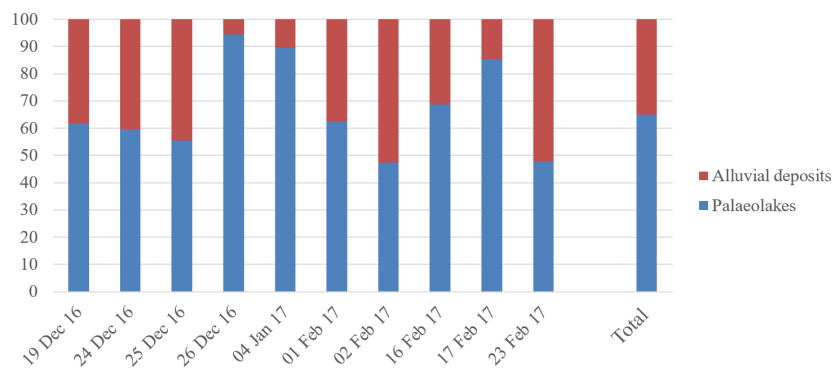

Figure 4. Contribution (in \%) of palaeolake dust sources versus alluvial deposit dust sources to total dust mass for the 10 largest dust storm events of the 2016-2017 winter dust season.

sources had no clear distinguishable features to place them in one of the geomorphic categories, and were thus labelled as "unknown".

During the 2015-2017 winter dust seasons a total of between 82.3 and $127.0 \mathrm{Tg}$ of dust was emitted (see Table 2). During the 2015-2016 dust season between 54.6 and $84.3 \mathrm{Tg}$ of dust was emitted, of which the 10 largest dust storms contributed $33.3 \%$, whereas the 10 largest dust storms of the 2016-2017 dust season produced $45.8 \%$ of the 27.7 $42.7 \mathrm{Tg}$ emitted that season. The 2015-2016 dust season was significantly more dusty, producing approximately twice the amount of dust compared with the 2016-2017 dust season, which is also reflected in the amount of individual dust point sources identified per season in Table 1 . The distribution of the dust over the various regions was, however, relatively similar in both seasons.

Table 2 shows the distribution of the emitted dust per dust source region, along with the frequency of emission, i.e. the percentage of days during which the region was an active dust source, the mean AOD, and the predominant geomorphology. The Bodélé Depression is identified as the single largest source region, emitting $44.5 \%$ of the dust mass, and producing the densest dust plumes with an average (arithmetic mean) AOD value of 0.91. The Bodélé, Bahr el Gazel, and Ennedi regions were the most frequently emitting dust source regions, with all of them emitting during more than half of the days of the wintertime dust season. Mauritania and southern Niger were the least active regions, emitting dust on only 2 of the $172 \mathrm{~d}$ analysed.

Dust source regions of predominantly palaeolake origin emitted approximately $64 \%$ of the total dust mass during the 2015-2017 winter dust seasons, compared with $36 \%$ for the dust regions governed by alluvial influence (note that southern Air and El Eglab are counted as $50 \%$ palaeolake and $50 \%$ alluvial deposit). However, the importance of palaeolakes and alluvial deposits fluctuated considerably. Figure 4 compares the influence of palaeolakes versus alluvial deposits for the 10 largest dust storms of the 2016-2017 winter dust season, which demonstrates this variability. 
Table 1. Northern African mineral dust point sources of the 2015-2017 winter dust seasons classified by geomorphology type.

\begin{tabular}{lrrrrrr}
\hline $\begin{array}{l}\text { Dust point source } \\
\text { geomorphology type }\end{array}$ & $\begin{array}{r}\text { Count } \\
15-16\end{array}$ & $\%$ & $\begin{array}{r}\text { Count } \\
16-17\end{array}$ & $\%$ & $\begin{array}{r}\text { Total } \\
\text { count }\end{array}$ & $\begin{array}{r}\text { Percent of } \\
\text { total }\end{array}$ \\
\hline Alluvial deposits & 1293 & 53.47 & 502 & 45.89 & 1795 & 51.11 \\
Palaeolakes & 992 & 41.03 & 513 & 46.89 & 1505 & 42.85 \\
Sand deposits & 82 & 3.39 & 56 & 5.12 & 138 & 3.93 \\
Stony surfaces & 19 & 0.79 & 15 & 1.37 & 34 & 0.97 \\
Unknown & 18 & 0.74 & 4 & 0.37 & 22 & 0.63 \\
Anthropogenic & 14 & 0.58 & 4 & 0.37 & 18 & 0.51 \\
\hline Total & 2418 & & 1094 & & 3512 & \\
\hline
\end{tabular}

Table 2. Total dust mass emitted per Saharan dust source region during the 2015-2017 winter dust seasons, alongside their predominant geomorphology, mean AOD, and their frequency of emission.

\begin{tabular}{|c|c|c|c|c|c|c|c|}
\hline & TG $15-16$ & TG $16-17$ & TG total & $\begin{array}{r}\text { Percent of } \\
\text { total }\end{array}$ & $\begin{array}{r}\text { Frequency (\% } \\
\text { days active) }\end{array}$ & $\begin{array}{l}\text { Mean } \\
\text { AOD }\end{array}$ & $\begin{array}{l}\text { Predominant } \\
\text { geomorphology }\end{array}$ \\
\hline Bodélé & $24.7-38.1$ & $11.9-18.4$ & $36.6-56.5$ & 44.5 & 67.4 & 0.91 & Palaeolake \\
\hline Bahr el Gazel & $5.9-9.2$ & $2.8-4.3$ & $8.7-13.5$ & 10.6 & 55.2 & 0.74 & Palaeolake \\
\hline Southern Air & $5.0-7.8$ & $3.3-5.0$ & $8.3-12.8$ & 10.1 & 43.6 & 0.40 & Alluvial deposit/palaeolake \\
\hline Northern Air & $5.3-8.2$ & $1.5-2.3$ & $6.8-10.5$ & 8.3 & 25.0 & 0.31 & Alluvial deposit \\
\hline Sudan & $4.6-7.0$ & $1.6-2.5$ & $6.2-9.5$ & 7.5 & 36.6 & 0.19 & Alluvial deposit \\
\hline Ennedi & $2.7-4.2$ & $2.1-3.2$ & $4.8-7.4$ & 5.8 & 54.7 & 0.28 & Alluvial deposit \\
\hline Algeria & $1.3-2.0$ & $1.1-1.7$ & $2.4-3.7$ & 2.9 & 12.8 & 0.32 & Palaeolake \\
\hline Tibesti & $1.8-2.7$ & $0.6-1.0$ & $2.4-3.7$ & 2.9 & 24.4 & 0.25 & Alluvial deposit \\
\hline Djado Plateau & $1.1-1.7$ & $0.4-0.7$ & $1.5-2.4$ & 1.9 & 12.2 & 0.37 & Alluvial deposit \\
\hline El Eglab & $0.4-0.6$ & $0.7-1.0$ & $1.1-1.6$ & 1.3 & 5.2 & 0.35 & Alluvial deposit/palaeolake \\
\hline Mid-Mali & $0.1-0.2$ & $0.8-1.2$ & $0.9-1.4$ & 1.1 & 4.7 & 0.42 & Alluvial deposit \\
\hline Upper Bodélé & $0.6-0.9$ & $0.2-0.4$ & $0.8-1.3$ & 1.0 & 22.7 & 0.22 & Alluvial deposit \\
\hline Draa River & $0.7-1.0$ & 0 & $0.7-1.0$ & 0.8 & 1.7 & 0.31 & Alluvial deposit \\
\hline Southern Niger & 0 & $0.5-0.8$ & $0.5-0.8$ & 0.6 & 1.2 & 0.65 & Alluvial deposit \\
\hline Mauritania & $0.3-0.5$ & $0.1-0.1$ & $0.4-0.6$ & 0.5 & 1.2 & 0.54 & Alluvial deposit \\
\hline Northwestern Mali & $0.1-0.2$ & $0.1-0.1$ & $0.2-0.3$ & 0.2 & 2.3 & 0.36 & Palaeolake \\
\hline Total & $54.6-84.3$ & $27.7-42.7$ & $82.3-127.0$ & & & & \\
\hline
\end{tabular}

\section{Discussion}

\subsection{Palaeolake and alluvial deposit dust sources}

Our results indicate the importance of both palaeolakes and alluvial deposits as African mineral dust sources. Alluvial deposits were found to deflate more often, whereas palaeolakes produced more dust by emitting denser dust plumes. Dry lakebeds, most notably the Bodélé Depression, are widely known to be preferential dust sources (Prospero et al., 2002; Tegen et al., 2002). Alluvial deposits, however, have been recognised to a much lesser extent in dust source studies, especially when compared with palaeolakes (Bullard et al., 2011). Producing $51.11 \%$ of the individual dust plumes and representing $\sim 36 \%$ of the total dust mass, alluvial deposits make a significant contribution to the dust burden. Despite this, the latest estimates of the fertilisation effect of dust on the Amazon by Yu et al. (2015) determine total phosphorus deposition into the Amazon $(0.022 \mathrm{Tg}$ per annum) based solely on the phosphorous concentration in Bodélé dust, while not taking alluvial deposit dust sources into account. Given the fact that it has recently been shown that there are significant differences in the bioavailable phosphorous content within dust from different source geomorphologies (Gross et al., 2015, 2016), and the evidence presented here that alluvial deposits are important sources, the accuracy of the estimate of Yu et al. (2015) can be questioned. In Namibia, Dansie et al. (2017) established that alluvial dust source sediments contained up to 43 times greater concentrations of bioavailable iron and enriched nitrogen $(\mathrm{N})$ and phosphorus $(\mathrm{P})$ macronutrients than palaeolake pan sediments. Further research into the actual differences in nutrient content of the different northern African dust sources and dust source geomorphologies is needed to improve the precision of fertilisation estimates. This is particularly the case for the under-examined alluvial source regions. 


\subsection{Do sand dunes produce dust?}

While palaeolakes and alluvial deposits accounted for over $90 \%$ of the emitted dust, sand deposits only accounted for $3.93 \%$. This contradicts recent results by Crouvi et al. (2012), who found that active sand dunes were the most frequent dust sources within the Sahara. The discrepancy between the results presented here and those found by Crouvi et al. (2012) is most likely explained by the type of data used and the difference in their spatial resolution. Crouvi et al. (2012) mapped dust sources onto a coarse-resolution $\left(1^{\circ} \times 1^{\circ}\right)$ grid, and compared them to a map of soils. When more than one soil type was present in a grid cell, Crouvi et al. (2012) assigned it to the geomorphic unit with the highest areal coverage. This carries a large bias towards widespread sand sheets and dune fields, whereas palaeorivers and small to medium-sized palaeolakes (which could be picked up with the high-resolution Sentinel-2 data utilised in this study), for instance, are underrepresented and easily overlooked. Another major difference between the studies is that Crouvi et al. (2012) classify the Bodélé region as sand dunes, whereas in this study it is classified as a palaeolake. While dunes exist in the Bodélé Depression, they are commonly composed of fragments of lake sediments and the dunes themselves are subordinate in cover to lake sediment exposures (Bristow et al., 2009). Furthermore, Crouvi et al. (2012) identified quartz-rich sand dune fields surrounding the Bodélé Depression as a major source of dust, although closer examination of the dust sources in this region, using high-resolution data from VIIRS and Sentinel-2, showed this was not the case. The higher-resolution data used in this study have improved the accuracy of dust source identification, and suggest that sand dunes produce little dust in northern Africa during wintertime.

\subsection{Location of dust sources}

The majority of the locations of dust sources identified in this study correspond to previous studies such as Prospero et al. (2002), Schepanski et al. (2007, 2009, 2012), Ginoux et al. (2012), and Knippertz and Todd (2012). However, one area that has not been widely recognised as a major source region is central/southern Sudan; only Schepanski et al. (2009) mentions this region. In southern Sudan, a few of the sources lie within the Sahel, but most are located in the Sahara. While various studies have analysed Sahelian dust emissions (Klose et al., 2010; Bergametti et al., 2017; Kim et al., 2017), less is known about the importance of the Sahel compared with the Sahara. From our data, we find that the Sahelian dust sources account for a mere $5 \%$, with the vast majority of the wintertime dust sources being located in the Sahara. Of the Sahelian dust sources, $87 \%$ are alluvial. The lack of lacustrine dust sources in the Sahel may be due to higher rainfall leading to moisture accumulation in the lake basins, which in turn suppresses dust production. The inundation of ephemeral lakes has previously been observed to lower dust emissions in semi-arid regions (Mahowald et al., 2003).

\section{Conclusions}

This study provides a quantitative analysis of wintertime northern African mineral dust sources. It outlines a novel methodology in which high temporal resolution remote sensing data are combined with high spatial resolution data to analyse dust sources more accurately than previous dust source studies. The results show the strong importance of alluvial deposits for the first time, while simultaneously reaffirming the importance of palaeolake sources. Sand deposits, in comparison, are found to produce relatively little dust. The results concur with previous studies that the Bodélé Depression is the single largest dust source region, yet also highlight that there are lesser studied regions, such as central Sudan, which are producing a substantial amount of dust. Furthermore, it stresses the significance of the Sahara over the Sahel regarding dust production, with $95 \%$ of dust sources emitting from the Sahara.

Data availability. SEVIRI data are available from the FENNEC project (http://www.fennec.imperial.ac.uk/, last access: September 2018). VIIRS data are available from NOAA CLASS (https:// www.avl.class.noaa.gov/, last access: September 2018). Sentinel2 data can be accessed through the ESA Copernicus Open Access Hub (https://scihub.copernicus.eu/dhus/T1\textbackslash\# /home, last access: July 2018). MODIS data are available from NASA Earthdata LAADS DAAC (https://ladsweb.modaps.eosdis. nasa.gov/, last access: December 2018). 


\section{Appendix A: Examples of geomorphic classes}

In the figures below, examples of the various geomorphic classes used in this study can be found. In order, the geomorphic categories are as follows: palaeolake (Fig. A1), alluvial deposit (Fig. A2), stony surface (Fig. A3), sand deposit (Fig. A4), and anthropogenic (Fig. A5).

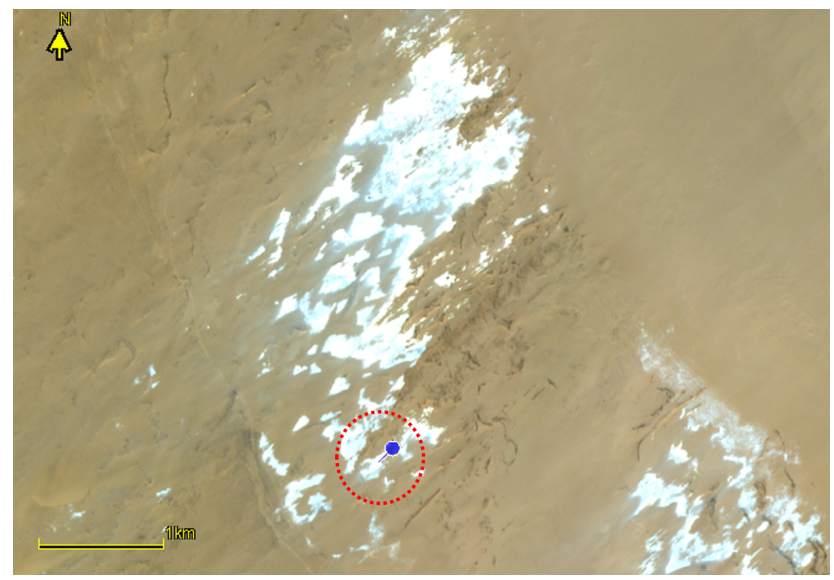

Figure A1. (C) Copernicus data (2019). Sentinel-2 natural colour composite showing a diatomite palaeolake in the Bodélé Depression region, Chad, identified as a dust source. This source emitted dust on 23 December 2015. The location of the pin is latitude 17.4875, longitude 19.4845. A $750 \mathrm{~m}$ buffer is included in red. Background: European Space Agency Copernicus Sentinel-2 data 2018. Sentinel-2 data are provided under the terms and conditions prescribed by the European Commission's Copernicus Programme. For detailed information on the data policy, appropriate usage, and citation of Sentinel data, please see: https://scihub.copernicus.eu/twiki/pub/SciHubWebPortal/ TermsConditions/TC_Sentinel_Data_31072014.pdf (last access: July 2018).

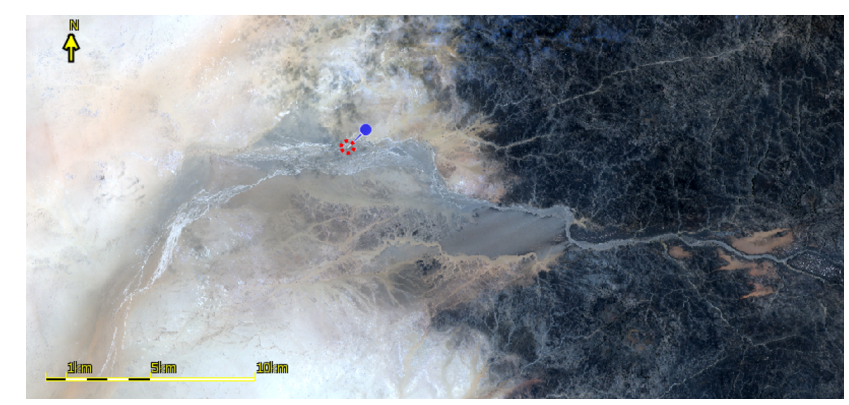

Figure A2. (C) Copernicus data (2019). Sentinel-2 natural colour composite showing an alluvial deposit dust source west of the Tibesti mountains in Chad. The source emitted dust on 30 November 2015. The location of the pin is latitude 21.4001, longitude 15.8211. A $750 \mathrm{~m}$ buffer is included in red. Background: European Space Agency Copernicus Sentinel-2 data 2018. Sentinel-2 data are provided under the terms and conditions prescribed by the European Commission's Copernicus Programme. For detailed information on the data policy, appropriate usage, and citation of Sentinel data, please see: https://scihub.copernicus.eu/twiki/pub/SciHubWebPortal/TermsConditions/TC_ Sentinel_Data_31072014.pdf (last access: July 2018). 


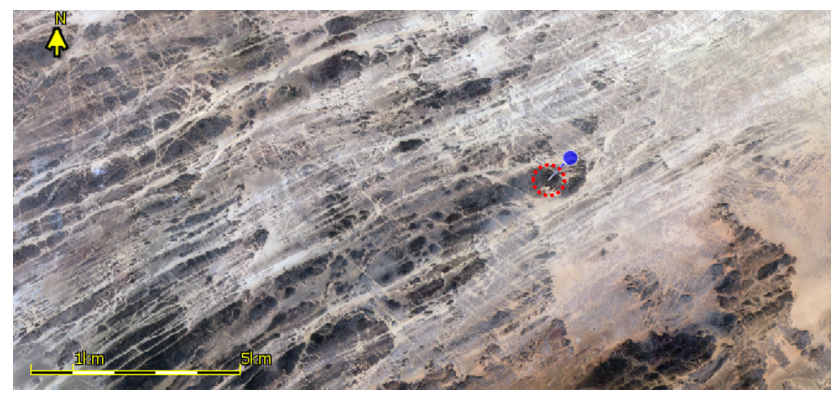

Figure A3. CCopernicus data (2019). Sentinel-2 natural colour composite showing a stony surface dust source near the border between Chad and Niger in the north. The source emitted dust on 1 December 2015. The location of the pin is latitude 22.2030, longitude 15.2052. A $750 \mathrm{~m}$ buffer is included in red. Background: European Space Agency Copernicus Sentinel-2 data 2018. Sentinel-2 data are provided under the terms and conditions prescribed by the European Commission's Copernicus Programme. For detailed information on the data policy, appropriate usage, and citation of Sentinel data, please see: https://scihub.copernicus.eu/twiki/pub/SciHubWebPortal/TermsConditions/TC_ Sentinel_Data_31072014.pdf (last access: July 2018).

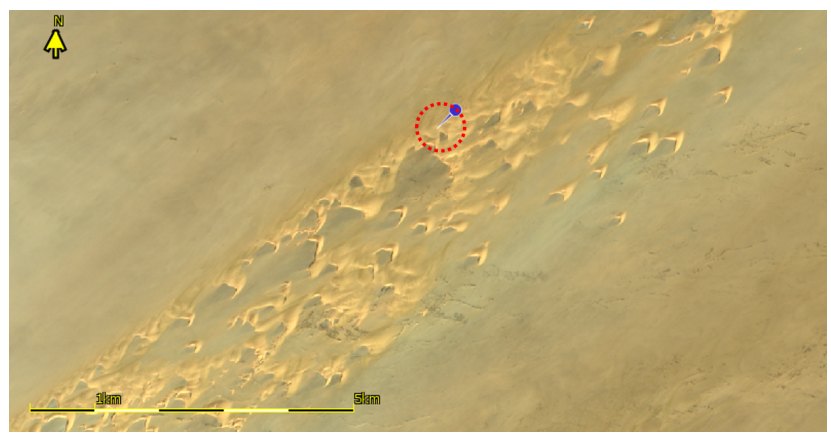

Figure A4. (C) Copernicus data (2019). Sentinel-2 natural colour composite showing a sand deposit (barchan dune) dust source, $\sim 35 \mathrm{~km}$ northeast of Faya-Largeau, Chad. This source emitted dust on 23 December 2015. The location of the pin is latitude 17.4655, longitude 19.6163. A $750 \mathrm{~m}$ buffer is included in red. Background: European Space Agency Copernicus Sentinel-2 data 2018. Sentinel-2 data are provided under the terms and conditions prescribed by the European Commission's Copernicus Programme. For detailed information on the data policy, appropriate usage, and citation of Sentinel data, please see: https://scihub.copernicus.eu/twiki/pub/SciHubWebPortal/TermsConditions/TC_ Sentinel_Data_31072014.pdf (last access: July 2018).

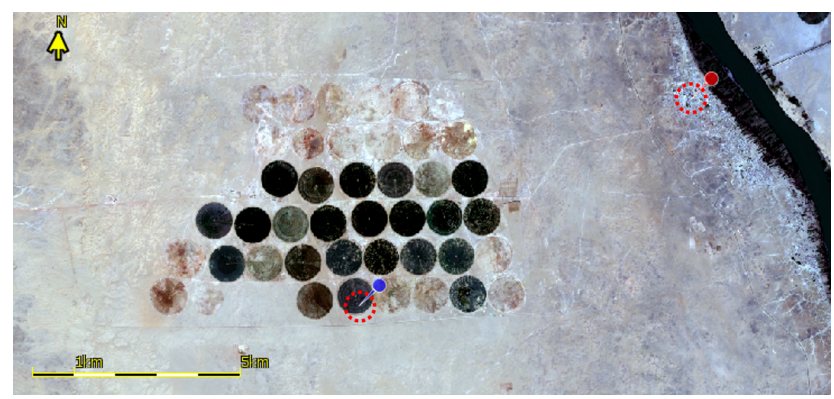

Figure A5. (C) Copernicus data (2019). Sentinel-2 natural colour composite showing two anthropogenic dust sources in Sudan. The agricultural dust source (blue pin) emitted dust on 21 February 2016. The location of the blue pin is latitude 18.7989, longitude 30.4026. The village dust source (red pin) emitted dust on 26 January 2016. The location of the red pin is latitude 18.8448 , longitude 30.4776 . A $750 \mathrm{~m}$ buffer included in red. Background: European Space Agency Copernicus Sentinel-2 data 2018. Sentinel-2 data are provided under the terms and conditions prescribed by the European Commission's Copernicus Programme. For detailed information on the data policy, appropriate usage, and citation of Sentinel data, please see: https://scihub.copernicus.eu/twiki/pub/SciHubWebPortal/TermsConditions/TC_Sentinel_Data_ 31072014.pdf (last access: July 2018). 
Author contributions. The conceptualisation and methodology of this research were established by NLB and NAD. Investigation and formal analysis were carried out by NLB, and supervised by NAD and CSB. The interpretation of results was determined from discussions involving all three authors. The original draft of the paper was written by NLB, and reviewed and edited by NAD and CSB.

Competing interests. The authors declare that they have no conflict of interest.

Acknowledgements. The authors would like to thank Ian Ashpole and an anonymous referee for reviewing the paper and providing valuable comments and suggestions. Moreover, we thank the editor Matthias Tesche.

Financial support. This research has been supported by the Natural Environment Research Council (grant no. NE/L002485/1).

Review statement. This paper was edited by Matthias Tesche and reviewed by Ian Ashpole and one anonymous referee.

\section{References}

Ansmann, A., Seifert, P., Tesche, M., and Wandinger, U.: Profiling of fine and coarse particle mass: case studies of Saharan dust and Eyjafjallajökull/Grimsvötn volcanic plumes, Atmos. Chem. Phys., 12, 9399-9415, https://doi.org/10.5194/acp12-9399-2012, 2012.

Ashpole, I. and Washington, R.: An automated dust detection using SEVIRI: A multiyear climatology of summertime dustiness in the central and western Sahara, J. Geophys. Res.-Atmos., 117, D08202, https://doi.org/10.1029/2011JD016845, 2012.

Ashpole, I. and Washington, R.: A new high-resolution central and western Saharan summertime dust source map from automated satellite dust plume tracking, J. Geophys. Res.-Atmos., 118, 6981-6995, https://doi.org/10.1002/jgrd.50554, 2013.

Ben-Ami, Y., Koren, I., Rudich, Y., Artaxo, P., Martin, S. T., and Andreae, M. O.: Transport of North African dust from the Bodélé depression to the Amazon Basin: a case study, Atmos. Chem. Phys., 10, 7533-7544, https://doi.org/10.5194/acp10-7533-2010, 2010.

Bergametti, G., Marticorena, B., Rajot, J. L., Chatenet, B., Féron, A., Gaimoz, C., Siour, G., Coulibaly, M., Koné, I., Maman, A., and Zakou, A.: Dust Uplift Potential in the Central Sahel: An Analysis Based on 10 years of Meteorological Measurements at High Temporal Resolution, J. Geophys. Res.-Atmos., 122, 12433-12448, https://doi.org/10.1002/2017JD027471, 2017.

Bristow, C. S., Drake, N., and Armitage, S.: Deflation in the dustiest place on Earth: The Bodélé Depression, Chad, Geomorphology, 105, 50-58, https://doi.org/10.1016/j.geomorph.2007.12.014, 2009.

Bristow, C. S., Hudson-Edwards, K. A., and Chappell, A.: Fertilizing the Amazon and equatorial Atlantic with
West African dust, Geophys. Res. Lett., 37, L14807, https://doi.org/10.1029/2010GL043486, 2010.

Bullard, J. E., Harrison, S. P., Baddock, M. C., Drake, N., Gill, T. E., McTainsh, G., and Sun, Y.: Preferential dust sources: A geomorphological classification designed for use in global dust-cycle models, J. Geophys. Res., 116, F04034, https://doi.org/10.1029/2011JF002061, 2011.

Chiapello, I., Bergametti, G., Chatenet, B., Bousquet, P., Dulac, F., and Soares, E. S.: Origins of African dust transported over the northeastern tropical Atlantic, J. Geophys. Res.-Atmos., 102, 13701-13709, https://doi.org/10.1029/97JD00259, 1997.

Crouvi, O., Schepanski, K., Amit, R., Gillespie, A. R., and Enzel, Y.: Multiple dust sources in the Sahara Desert: The importance of sand dunes, Geophys. Res. Lett., 39, L13401, https://doi.org/10.1029/2012GL052145, 2012.

Dansie, A. P., Wiggs, G. F. S., and Thomas, D. S. G.: Iron and nutrient content of wind-erodible sediment in the ephemeral river valleys of Namibia, Geomorphology, 290, 335-346, https://doi.org/10.1016/j.geomorph.2017.03.016, 2017.

Drake, N. A., Handley, R., O'Loingsigh, T., Brooks, N., and Bryant, R.: Identifying Saharan dust sources using remote sensing: a comparison of TOMS AI, Meteosat IDDI and a new MODIS Dust Index, Geophysical Research Abstracts (EGU Conference 2008), Volume 10, available at: http://hdl.handle.net/10072/ 40935, 2008.

FENNEC: SEVIRI DUST RGB, available at: http://www.fennec. imperial.ac.uk/ (last access: 1 September 2018), 2019.

Formenti, P., Schütz, L., Balkanski, Y., Desboeufs, K., Ebert, M., Kandler, K., Petzold, A., Scheuvens, D., Weinbruch, S., and Zhang, D.: Recent progress in understanding physical and chemical properties of African and Asian mineral dust, Atmos. Chem. Phys., 11, 8231-8256, https://doi.org/10.5194/acp11-8231-2011, 2011.

Gebhart, K. A., Schichtel, B. A., and Barna, M. G.: Directional biases in back trajectories caused by model and input data., J. Air Waste Manag. Assoc., 55, 1649-1662, https://doi.org/10.1080/10473289.2005.10464758, 2005.

Ginoux, P., Prospero, J. M., Gill, T. E., Hsu, N. C., and Zhao, M.: Global-scale attribution of anthropogenic and natural dust sources and their emission rates based on MODIS Deep Blue aerosol products, Rev. Geophys., 50, 2012RG000388, https://doi.org/10.1029/2012RG000388, 2012.

Gross, A., Goren, T., Pio, C., Cardoso, J., Tirosh, O., Todd, M. C., Rosenfeld, D., Weiner, T., Custódio, D., and Angert, A.: Variability in Sources and Concentrations of Saharan Dust Phosphorus over the Atlantic Ocean, Environ. Sci. Technol. Lett., 2, 31-37, https://doi.org/10.1021/ez500399z, 2015.

Gross, A., Palchan, D., Krom, M. D., and Angert, A.: Elemental and isotopic composition of surface soils from key Saharan dust sources, Chem. Geol., 442, 54-61, https://doi.org/10.1016/j.chemgeo.2016.09.001, 2016.

Harrison, S. P., Kohfeld, K. E., Roelandt, C., and Claquin, T.: The role of dust in climate changes today, at the last glacial maximum and in the future, Earth-Sci. Rev., 54, 43-80, https://doi.org/10.1016/S0012-8252(01)00041-1, 2001.

Haywood, J., Francis, P., Osborne, S., Glew, M., Loeb, N., Highwood, E., Tanré, D., Myhre, G., Formenti, P., and Hirst, E.: Radiative properties and direct radiative effect of Saharan dust measured by the C-130 aircraft during 
SHADE: 1. Solar spectrum, J. Geophys. Res., 108, 8577, https://doi.org/10.1029/2002JD002687, 2003.

Hsu, N. C., Tsay, S.-C., King, M. D., and Herman, J. R.: Aerosol Properties Over Bright-Reflecting Source Regions, IEEE T. Geosci. Remote Sens., 42, 557-569, https://doi.org/10.1109/TGRS.2004.824067, 2004.

Jickells, T. D., An, Z. S., Andersen, K. K., Baker, A. R., Bergametti, G., Brooks, N., Cao, J. J., Boyd, P. W., Duce, R. A., Hunter, K. A., Kawahata, H., Kubilay, N., laRoche, J., Liss, P. S., Mahowald, N., Prospero, J. M., Ridgwell, A. J., Tegen, I., and Torres, R.: Global Iron Connections Between Desert Dust, Ocean Biogeochemistry, and Climate, Science, 308, 67-71, 2005.

Kaufman, Y. J., Tanré, D., Remer, L. A., Vermote, E. F., Chu, A., and Holben, B. N.: Operational remote sensing of tropospheric aerosol over land from EOS moderate resolution imaging spectroradiometer, J. Geophys. Res.-Atmos., 102, 17051-17067, https://doi.org/10.1029/96JD03988, 1997.

Kaufman, Y. J., Koren, I., Remer, L. A., Tanré, D., Ginoux, P., and Fan, S.: Dust transport and deposition observed from the Terra-Moderate Resolution Imaging Spectroradiometer (MODIS) spacecraft over the Atlantic Ocean, J. Geophys. Res., 110, D10S12, https://doi.org/10.1029/2003JD004436, 2005.

Kim, D., Chin, M., Remer, L. A., Diehl, T., Bian, H., Yu, H., Brown, M. E., and Stockwell, W. R.: Role of surface wind and vegetation cover in multi-decadal variations of dust emission in the Sahara and Sahel, Atmos. Environ., 148, 282-296, https://doi.org/10.1016/J.ATMOSENV.2016.10.051, 2017.

Klose, M., Shao, Y., Karremann, M. K., and Fink, A. H.: Sahel dust zone and synoptic background, Geophys. Res. Lett., 37, L09802, https://doi.org/10.1029/2010GL042816, 2010.

Knippertz, P. and Todd, M. C.: Mineral dust aerosols over the Sahara: Meteorological controls on emission and transport and implications for modeling, Rev. Geophys., 50, RG1007, https://doi.org/10.1029/2011RG000362, 2012.

Koren, I., Kaufman, Y. J., Washington, R., Todd, M. C., Rudich, Y., Martins, J. V., and Rosenfeld, D.: The Bodélé depression?: a single spot in the Sahara that provides most of the mineral dust to the Amazon forest, Environ. Res. Lett., 1, 14005-14005, https://doi.org/10.1088/1748-9326/1/1/014005, 2006.

Lensky, I. M. and Rosenfeld, D.: Clouds-Aerosols-Precipitation Satellite Analysis Tool (CAPSAT), Atmos. Chem. Phys., 8, 6739-6753, https://doi.org/10.5194/acp-8-6739-2008, 2008.

Levy, R. C., Mattoo, S., Munchak, L. A., Remer, L. A., Sayer, A. M., Patadia, F., and Hsu, N. C.: The Collection 6 MODIS aerosol products over land and ocean, Atmos. Meas. Tech., 6, 29893034, https://doi.org/10.5194/amt-6-2989-2013, 2013.

Mahowald, N. M., Bryant, R. G., del Corral, J., and Steinberger, L.: Ephemeral lakes and desert dust sources, Geophys. Res. Lett., 30, 1074, https://doi.org/10.1029/2002GL016041, 2003.

Mahowald, N. M., Kloster, S., Engelstaedter, S., Moore, J. K., Mukhopadhyay, S., McConnell, J. R., Albani, S., Doney, S. C., Bhattacharya, A., Curran, M. A. J., Flanner, M. G., Hoffman, F. M., Lawrence, D. M., Lindsay, K., Mayewski, P. A., Neff, J., Rothenberg, D., Thomas, E., Thornton, P. E., and Zender, C. S.: Observed 20th century desert dust variability: impact on climate and biogeochemistry, Atmos. Chem. Phys., 10, 10875-10893, https://doi.org/10.5194/acp-10-10875-2010, 2010.
Muhs, D. R., Prospero, J. M., Baddock, M. C., and Gill, T. E.: Identifying Sources of Aeolian Mineral Dust?: Present and Past, in: Mineral dust: A key player in the earth system, edited by: Stuut, J.-B. W., Springer, Dordrecht, 51-74, 2014.

Prospero, J. M., Ginoux, P., Torres, O., Nicholson, S. E., and Gill, T. E.: Environmental characterization of global sources of atmospheric soil dust identified with the NIMBUS 7 Total Ozone Mapping Spectrometer (TOMS) absorbing aerosol product, Rev. Geophys., 40, 1002, https://doi.org/10.1029/2000RG000095, 2002.

Ridley, D. A., Heald, C. L., and Ford, B.: North African dust export and deposition: A satellite and model perspective, J. Geophys. Res.-Atmos., 117, D02202, https://doi.org/10.1029/2011JD016794, 2012.

Sayer, A. M., Hsu, N. C., Bettenhausen, C., and Jeong, M.-J.: Validation and uncertainty estimates for MODIS Collection 6 ''Deep Blue" aerosol data, J. Geophys. Res.-Atmos., 118, 7864-7872, https://doi.org/10.1002/jgrd.50600, 2013.

Schepanski, K., Tegen, I., Laurent, B., Heinold, B., and Macke, A.: A new Saharan dust source activation frequency map derived from MSG-SEVIRI IR-channels, Geophys. Res. Lett., 34, L18803, https://doi.org/10.1029/2007GL030168, 2007.

Schepanski, K., Tegen, I., Todd, M. C., Heinold, B., Bönisch, G., Laurent, B., and Macke, A.: Meteorological processes forcing Saharan dust emission inferred from MSGSEVIRI observations of subdaily dust source activation and numerical models, J. Geophys. Res., 114, D10201, https://doi.org/10.1029/2008JD010325, 2009.

Schepanski, K., Tegen, I., and Macke, A.: Comparison of satellite based observations of Saharan dust source areas, Remote Sens. Environ., 123, 90-97, https://doi.org/10.1016/j.rse.2012.03.019, 2012.

Scheuvens, D., Schütz, L., Kandler, K., Ebert, M., and Weinbruch, S.: Bulk composition of northern African dust and its source sediments - A compilation, Earth-Sci. Rev., 116, 170 194, https://doi.org/10.1016/J.EARSCIREV.2012.08.005, 2013.

Swap, R., Garstang, M., Greco, S., Talbot, R., and Kållberg, P.: Saharan dust in the Amazon Basin, Tellus, 44B, 133-149, https://doi.org/10.1034/j.1600-0889.1992.t01-1-00005.x, 1992.

Tegen, I., Harrison, S. P., Kohfeld, K., Prentice, I. C., Coe, M., and Heimann, M.: Impact of vegetation and preferential source areas on global dust aerosol: Results from a model study, J. Geophys. Res.-Atmos., 107, AAC 14-1-AAC 14-27, https://doi.org/10.1029/2001JD000963, 2002.

Washington, R., Todd, M., Middleton, N. J., and Goudie, A. S.: Dust-Storm Source Areas Determined by the Total Ozone Monitoring Spectrometer and Surface Observations, Ann. Assoc. Am. Geogr., 93, 297-313, https://doi.org/10.1111/14678306.9302003, 2003.

Yu, H., Chin, M., Yuan, T., Bian, H., Remer, L. A., Prospero, J. M., Omar, A., Winker, D., Yang, Y., Zhang, Y., Zhang, Z., and Zhao, C.: The fertilizing role of African dust in the Amazon rainforest: A first multiyear assessment based on data from Cloud-Aerosol Lidar and Infrared Pathfinder Satellite Observations, Geophys. Res. Lett., 42, 1984-1991, https://doi.org/10.1002/2015GL063040, 2015. 